
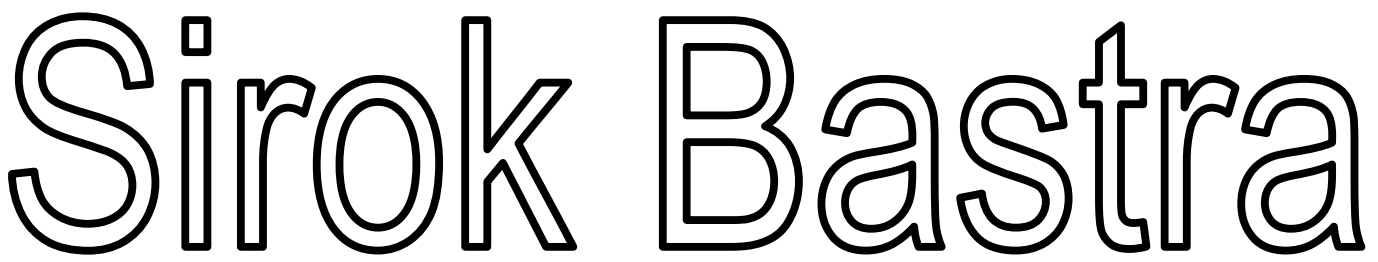

JURNAL ILMIAH KEBAHASAAN DAN KESASTRAAN

\begin{tabular}{|c|c|c|c|c|c|}
\hline $\begin{array}{c}\text { Sirok Bastra } \\
\text { Jurnal Kebahasaan dan } \\
\text { Kesastraan }\end{array}$ & Volume 2 & Nomor 2 & $\begin{array}{c}\text { Hlm. } \\
121-210\end{array}$ & $\begin{array}{l}\text { Pangkalpinang, } \\
\text { Desember 2014 }\end{array}$ & $\begin{array}{c}\text { ISSN } \\
2354-7200\end{array}$ \\
\hline
\end{tabular}

KANTOR BAHASA PROVINSI BANGKA BELITUNG 


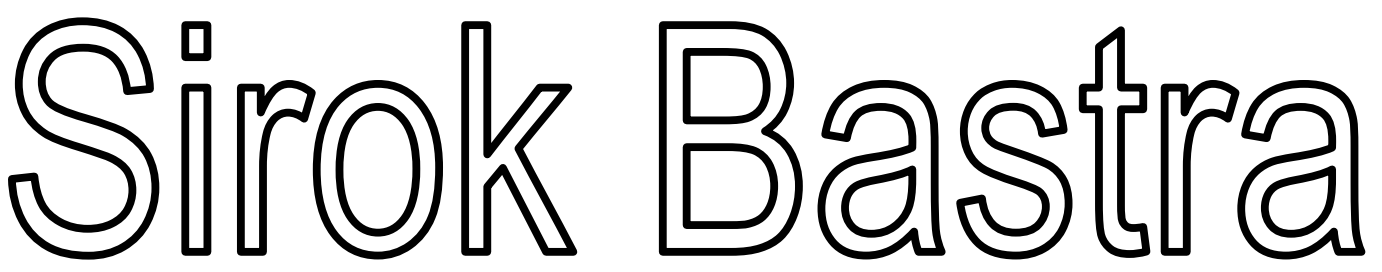

JURNAL ILMIAH KEBAHASAAN DAN KESASTRAAN

Jurnal ini merupakan wadah informasi mengenai kebahasan, kesastraan, dan pengajarannya yang memuat hasil penelitian, studi kepustakaan, dan tulisan ilmiah bidang kebahasan dan kesastraan serta pengajarannya. Sirok Bastra terbit dua kali setahun, yakni Juni dan Desember, serta terbit sejak Juni 2013.

\section{Penanggung Jawab}

Kepala Kantor Bahasa Provinsi Bangka Belitung Drs. Umar Solikhan, M.Hum.

Mitra Bestari

Prof. Dr. Agus Nuryatin, M.Hum. (Bidang Sastra dan Pengajarannya)

Prof. Amrin Saragih, Ph.D., M.A. (Bidang Bahasa dan Pengajarannya)

Dr. Felicia Nuradi Utorodewo, M.Hum. (Bidang Bahasa dan Pengajarannya)

Dr. Pujiharto, M.Hum. (Bidang Sastra dan Pengajarannya)

\section{Pemimpin Redaksi}

Rahmat Muhidin, S.S.

\section{Penyunting}

Prima Hariyanto, S.Hum.

\section{Perancang Sampul}

Feri Pristiawan, S.S.

\section{Kesekretariatan}

Khaliffitriansyah, S.Pd.

Dea Letriana Cesaria, S.Hum.

Lia Aprilina, S.Pd.

Andrian Priyatno, A.Md.

Elzam

\section{Alamat Redaksi dan Penerbit}

Kantor Bahasa Provinsi Bangka Belitung

Ruko Permata 7, Jalan Solihin G.P. Km 4, Kota Pangkalpinang, Prov. Kepulauan Bangka Belitung

Telp./Faks.: 0717-438455, Pos-el: sirokbastra@gmail.com, sirokbastra@kemdikbud.go.id

Pemuatan suatu tulisan dalam jurnal ini tidak berarti redaksi menyetujui isi tulisan tersebut. Isi tulisan menjadi tanggung jawab penulis. Tulisan telah ditinjau dan diulas oleh mitra bestari. Setiap karangan dalam jurnal ini dapat diperbanyak setelah mendapat izin tertulis dari penulis, redaksi, dan penerbit. 


\section{PENGANTAR}

Puji syukur ke hadirat Pemilik dan Pencipta semesta ini yang memiliki kuasa atas diri-Nya sendiri. Dialah Tuhan Yang Maha Esa yang telah memberikan rahmat dan hidayah-Nya sehingga Volume 2 Nomor 2 Jurnal Sirok Bastra Tahun 2014 dapat terbit tepat pada waktunya.

Pada edisi ini, dimuat sepuluh tulisan, yakni satu tulisan kebahasaan, satu tulisan pengajaran bahasa, dan delapan tulisan kesastraan. Dalam penelitiannya, Anitawati Bachtiar, Adek Dwi Oktaviantina, dan Rukmini membahas penggunaan alih kode dan campur kode pada dialog ubrug. Berdasarkan penelitian, ditemukan bentuk alih kode intern, berupa peralihan dari bahasa Jawa Serang menjadi Sunda Banten dan sebaliknya, serta alih kode metaforis dan situasional. Terdapat pula campur kode ke dalam yang berbentuk penyisipan kata pada kalimat yang diucapkan para pemain. Tujuan penggunaan alih kode dan campur kode itu adalah untuk memecah kekakuan saat pementasan, serta membangkitkan rasa humor agar penonton dapat terhibur.

Abdul Aziz melakukan penelitian yang bertujuan untuk mengupayakan peningkatan keterampilan siswa dalam menulis paragraf melalui metode inkuiri dengan menggunakan media audio pada siswa kelas $\mathrm{X}_{1}$ SMA DDI Alliritengae, Kabupaten Maros. Hasil penelitian menunjukkan bahwa metode inkuiri dengan menggunakan media audio dapat meningkatkan kemampuan menulis paragraf siswa kelas $\mathrm{X}_{1}$ SMA DDI Alliritengae, Kabupaten Maros pada tahap pelaksanaan dan tahap penilaian.

Dalam kajiannya, Tri Lia memaparkan nilai sosial dan budaya dalam cerita pendek "Sri Sumarah" karya Umar Kayam. Berdasarkan analisis, ditemukan beberapa nilai sosial budaya yang terdapat dalam cerita pendek ini, yaitu wayang dan stratifikasi sosial, masyarakat Jawa yang nrimo, sistem sapaan dalam masyarakat Jawa, mistik kejawen, masyarakat Jawa yang pembalas budi, keselarasan hidup masyarakat Jawa, dan latar politik PKI.

Dalam kajiannya, Dindin Samsudin membandingkan teka-teki (pertanyaan tradisional) yang terdapat di Provinsi Nanggroe Aceh Darussalam, yakni hiem dan yang terdapat di Provinsi Jawa Barat, yakni tatarucingan. Berdasarkan penelitian, terdapat beberapa hiem Aceh dan tatarucingan Sunda yang memiliki persamaan.

Dalam kajiannya, Kurniati membahas novel Orang-Orang Proyek karya Ahmad Tohari yang menurutnya berusaha menghadirkan sebuah realitas kemanusiaan, yakni melawan korupsi dan berbagai penyimpangan. Penulis menunjukkan bahwa di dalam novel tersebut terdapat kebenaran sosial. Karya ini memiliki sebab dan hasil kehebatan nilai artistik sebuah karya sastra (dengan dokumen sosialnya) sebagai potret kenyataan sosial.

Dalam penelitiannya, Sony Sukmawan membahas apokaliptisme sastra lisan Lereng Arjuna. Ciri-ciri yang terdapat dalam sastra lisan Lereng Arjuna dalam wujud (i) pemahlawanan tokoh mitologis dan sosok cikal bakal, trindih ukir, atau babat alas desa setempat; (ii) implikasi gagasan apokaliptik di balik latar penamaan desa, latar penamaan situs-situs purbakala, dan situs keramat alami; (iii) penamaan para-baureksa dalam mantra; serta (iv) pengungkapan apokaliptik sebagai pemulihan stabilitas alam melalui tindakan pencegahan yang persuasif.

Hestiyana membahas tema dan amanat cerita rakyat di Kecamatan Karang Intan, Kabupaten Banjar. Dalam penelitiannya, ditemukan tiga bentuk cerita rakyat, yaitu dongeng, legenda, dan mite. Cerita rakyat tersebut terdiri atas satu dongeng yang berjudul "Ular Tadung di Gunung Kiyau"; dua legenda berjudul "Asal Usul Nama Desa Karang Intan" dan "Asal Usul Nama Danau Purun"; dan satu mite berjudul "Pamandian Putri di Gunung Putra Bulu".

Dalam penelitiannya, Helmina Kastanya membahas tradisi lisan tatabuang manare dan badendang yang merupakan salah satu kekayaan sastra yang mengandung nilai estetika dalam pesta pernikahan masyarakat Pulau Ambon. Berdasarkan penelitian, bentuk tradisi lisan tatabuang manare dan badendang adalah prosesi berbalas pantun sambil menari diiringi alunan musik totobuang dan tifa. Tradisi ini berfungsi sebagai media penyatuan dua keluarga yang baru menjadi besan. Adapun nilai yang terkandung di dalamnya adalah nilai percintaan, kekeluargaan, dan sosial.

Dalam penelitiannya, Bagus Kurniawan membahas strategi pembacaan dekonstruksi karakter Arjuna sebagai lelananging jagad dalam lakon-lakon wayang purwa. Menurutnya, pemaknaan terhadap wayang masa kini mulai beragam, tidak hanya melalui dikotomi hitam-putih, tetapi juga melalui berbagai tafsir yang kemudian 
mendekonstruksi makna yang sudah mapan. Dalam tulisan ini, diuraikan strategi pembacaan secara dekonstruksi terhadap karakter Arjuna dengan menggunakan beberapa lakon wayang berbahasa Indonesia yang diterbitkan di majalah Cempala.

Mulawati mengkaji nilai karakter bangsa dalam nyanyian rakyat Muna di Provinsi Sulawesi Tenggara. Berdasarkan penelitian, unsur intrinsik nyanyian rakyat Muna menyiratkan nilai-nilai karakter bangsa seperti disiplin, selalu bekerja keras, mandiri, kreatif, dan toleransi.

Kami mengucapkan terima kasih kepada para penulis yang telah bersedia menerbitkan karya mereka pada edisi ini. Para penulis merupakan peneliti, pakar, dosen, guru, dan mahasiswa dari berbagai sekolah, perguruan tinggi, dan instansi. Terima kasih juga kami sampaikan kepada para mitra bestari yang telah memberi ulasan terhadap tulisan-tulisan yang masuk ke redaksi.

Demi memenuhi keberagaman isi dan penulis, Sirok Bastra membuka kesempatan bagi para peneliti dan penulis untuk menyampaikan hasil penelitian dan pemikiran mutakhir dalam bidang kebahasaan, kesastraan, dan pengajarannya.

Pangkalpinang, Desember 2014

\section{Tim Redaksi}




\section{UCAPAN TERIMA KASIH UNTUK MITRA BESTARI}

Redaksi Sirok Bastra mengucapkan terima kasih kepada para mitra bestari yang telah meninjau, menimbang, dan mengulas makalah-makalah yang diterbitkan dalam Sirok Bastra Volume 2 Nomor 2, edisi Desember 2014, yakni

\section{Prof. Dr. Agus Nuryatin, M.Hum.}

Bidang Sastra dan Pengajarannya

Universitas Negeri Semarang

Semarang, Jawa Tengah

Prof. Amrin Saragih, Ph.D., M.A.

Bidang Bahasa dan Pengajarannya

Universitas Negeri Medan

Medan, Sumatra Utara

\section{Dr. Felicia Nuradi Utorodewo, M.Hum.}

Bidang Bahasa dan Pengajarannya

Universitas Indonesia

Depok, Jawa Barat

\section{Dr. Pujiharto, M.Hum.}

Bidang Sastra dan Pengajarannya

Universitas Gadjah Mada

Yogyakarta, Daerah Istimewa Yogyakarta 


\section{DAFTAR ISI}

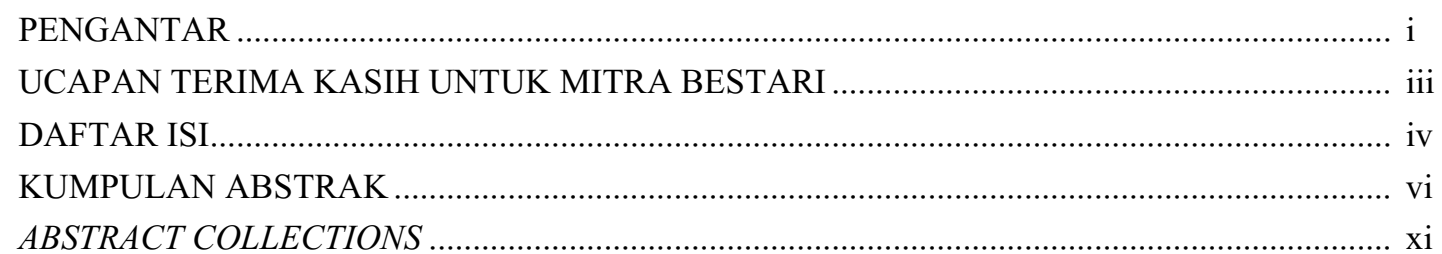

\section{UBRUG: KAJIAN SOSIOLINGUISTIK}

(Ubrug: Sociolinguistic Study)

Anitawati Bachtiar, Adek Dwi Oktaviantina, dan Rukmini $121-128$

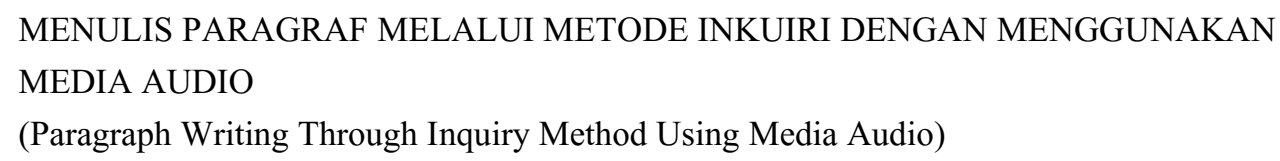

TEMA DAN AMANAT CERITA RAKYAT DI KECAMATAN KARANG INTAN, KABUPATEN BANJAR

(Theme and Message of Folklore in Karang Intan Subdistrict, Banjar Regency)

TATABUANG MANARE DAN BADENDANG DALAM PESTA PERNIKAHAN MASYARAKAT PULAU AMBON

(Tatabuang Manare and Badendang in Wedding Party of Ambon Island Society) 
MENGGUGAT ARJUNA SEBAGAI LELANANGING JAGAD: SEBUAH STRATEGI PEMBACAAN DEKONSTRUKSI KARAKTER ARJUNA DALAM LAKON-LAKON WAYANG PURWA

(Arjuna Sued as A Man of Universe: The Deconstruction of Reading Strategy for Arjuna's Character on Purwa Puppet Shows)

Bagus Kurniawan $193-200$

NILAI KARAKTER BANGSA DALAM NYANYIAN RAKYAT MUNA

(Nation Character Values in Munanese Folksong)

Mulawati $201-201$ 
Abdul Aziz : Menulis Paragraf melalui Metode Inkuiri dengan Menggunakan Media Audio

\title{
MENULIS PARAGRAF MELALUI METODE INKUIRI DENGAN MENGGUNAKAN MEDIA AUDIO
}

\author{
Paragraph Writing Through Inquiry Method Using Media Audio
}

\author{
Abdul Azis \\ JBSI FBS Universitas Negeri Makassar \\ Jalan Dg. Tata Raya FBS UNM, Makassar, Sulawesi Selatan 90222 \\ Pos-el: azissa17@yahoo.co.id
}

(diterima 19 Februari 2014, disetujui 3 Juni 2014, revisi terakhir 1 Juli 2014)

\begin{abstract}
Abstrak
Penelitian ini bertujuan untuk mengupayakan peningkatan keterampilan siswa dalam menulis paragraf melalui metode inkuiri dengan menggunakan media audio pada siswa kelas $\mathrm{X}_{1}$ SMA DDI Alliritengae, Kabupaten Maros. Penelitian ini merupakan penelitian tindakan kelas (PTK). Teknik pengumpulan data yang digunakan adalah obsevasi, wawancara, dan unjuk kerja. Pemaparan data proses dianalisis dengan teknik deskriptif kualitatif, sedangkan pemaparan data hasil penelitian dianalisis dengan teknik deskriptif kuantitatif. Hasil penelitian menunjukkan bahwa metode inkuiri dengan menggunakan media audio dapat meningkatkan kemampuan menulis paragraf siswa kelas $\mathrm{X}_{1}$ SMA DDI Alliritengae, Kabupaten Maros pada tahap pelaksanaan dan tahap penilaian. Hasil analisis penilaian siswa menunjukkan bahwa pada siklus I nilai rata-rata siswa sebesar 74,86 dengan persentase tingkat penguasaan berada dalam kategori cukup (66-75), pada siklus II nilai rata-rata siswa mencapai 86,33 dengan persentase tingkat penguasaan berada dalam kategori baik sekali (86-95). Hal ini menunjukkan bahwa pada siklus II telah mengalami peningkatan sebanyak 11,47 dari siklus I. Berdasarkan hasil penelitian disimpulkan bahwa penerapan metode inkuiri dengan menggunakan media audio dapat meningkatkan kemampuan menulis paragraf siswa kelas $\mathrm{X}_{1}$ SMA DDI Alliritengae, Kabupaten Maros.
\end{abstract}

Kata kunci: paragraf, metode inkuiri, media audio

\begin{abstract}
This study aims to strive to increase students' skills in writing paragraphs through the inquiry method using audio media in class X1SMA DDI Alliritengae Maros. This research is classified into Classroom Action Research (CAR). Data collection techniques used were observation, interviews, and performance. Exposure process data were analyzed with descriptive qualitative techniques, while the exposure of the data were analyzed with descriptive quantitative techniques. The results showed that the method of inquiry by using the audio media to enhance the student's ability to write paragraphs high school class X1 DDI Alliritengae Maros on the implementation phase and the assessment phase. The results of student assessment analysis showed that in the first cycle the average value of 74.86 with the percentage of students at mastery levels are within the category of pretty (66-75), the second cycle of the average value of 86.33 with the percentage of students achieving mastery levels are in excellent category (86-95). This suggests that the second cycle has increased by 11.47 of cycle I. Based on the results of the study concluded that the application of the method of inquiry by using the audio media to enhance the student's ability to write paragraphs high school class X1 DDI Alliritengae Maros.
\end{abstract}

Keywords: paragraphs, methods inkuiri, audio media

\section{PENDAHULUAN}

\subsection{Latar Belakang}

Pembelajaran bahasa Indonesia pada dasarnya bertujuan meningkatkan kemampuan siswa menggunakan bahasa sebagai alat komunikasi, baik secara lisan maupun secara tertulis. Kemampuan siswa berkomunikasi secara tertulis yang dimaksud adalah kemampuan menulis. Khusus untuk pembelajaran keterampilan menulis dalam aspek kebahasaan, salah satu bentuk pembelajarannya adalah menulis paragraf. Paragraf pun terbagi dari beberapa jenis, yakni paragraf narasi, deskripsi, persuasif, eksposisi, dan argumentatif. 


\subsection{Masalah}

Dalam menulis paragraf, sering dijumpai berbagai kesulitan. Untuk mengatasi masalah tersebut, dibutuhkan metode yang tepat. Menurut Wina Sanjaya (2008:191), metode inkuiri merupakan metode pembelajaran yang menekankan pada proses berpikir secara kritis dan analitis untuk mencari dan menemukan sendiri. Pada penerapan metode inkuiri, peserta didik diharapkan mampu menemukan dan memecahkan sendiri masalah yang dihadapi.

Untuk mendukung keberhasilan pembelajaran dan menciptakan kondisi pembelajaran yang lebih menarik, peneliti menggunakan media pembelajaran, yakni media audio. Media audio merupakan media yang hanya dapat memberikan rangsangan suara saja (Haling dkk., 2007:101). Penggunaan media audio dalam proses pembelajaran mampu merangsang siswa untuk berpikir.

\subsection{Tujuan}

Penelitian ini bertujuan untuk mengetahui dan mendeskripsikan peningkatan pembelajaran menulis paragraf melalui metode inkuiri dengan menggunakan media audio pada siswa, dengan menjabarkan tujuan yang ingin dicapai sebagai berikut.

1. Mendeskripsikan peningkatan pelaksanaan pembelajaran menulis paragraf melalui metode inkuiri dengan menggunakan media audio pada siswa.

2. Mendeskripsikan peningkatan hasil penilaian kemampuan menulis paragraf melalui metode inkuiri dengan menggunakan media audio pada siswa.

\subsection{Manfaat}

Manfaat penelitian ini diklasifikasikan menjadi dua, yaitu manfaat teoretis dan manfaat praktis. Secara teoretis, penelitian ini dapat menambah referensi bagi pembaca atau peneliti lain dalam mencari referensi tentang pembelajaran menulis paragraf dan memberikan sumbangan dalam ilmu pengetahuan berupa pengembangan teori-teori yang berhubungan dengan pengajaran bahasa Indonesia, khususnya keterampilan menulis paragraf.

Secara praktis, penelitian ini diharapkan dapat membantu siswa yang mengalami kesulitan dalam menulis paragraf; memberikan pengetahuan berupa informasi tentang metode atau media yang variatif dalam pelaksanaan pembelajaran menulis paragraf. Hal ini dilakukan agar guru dapat melakukan inovasi dalam penerapan berbagai metode dan penggunaan media pembelajaran di kelas dengan tujuan untuk meningkatkan hasil pembelajaran siswa; meningkatkan mutu dan efektivitas pembelajaran di sekolah; dan memberikan pengetahuan tentang penerapan dan penggunaan media yang efektif dalam proses pembelajaran. Hal tersebut dijadikan oleh peneliti sebagai bekal dalam menjadi tenaga pendidik yang profesional pada masa yang akan datang; dan menjadi acuan atau pedoman dalam melakukan penelitian tindakan kelas, khususnya yang terkait dengan pengembangan keterampilan menulis paragraf melalui metode inkuiri dan media audio.

\subsection{Metode}

Dalam penelitian ini, peneliti menggunakan prosedur penelitian tindakan kelas. Penelitian ini dilaksanakan di SMA DDI Alliritengae, Kabupaten Maros, Sulawesi Selatan. Subjek penelitian ini adalah seluruh siswa kelas $\mathrm{X}_{1}$ SMA DDI Alliritengae, Kabupaten Maros yang berjumlah 29 siswa. Kelas ini merupakan kelas heterogen dengan seorang guru bahasa Indonesia. Data penelitian berupa data pelaksanaan dan data evaluasi. Data penelitian diperoleh melalui wawancara, teknik observasi, dan tes dari setiap tindakan penerapan metode inkuiri dan penggunaan media audio dalam pembelajaran menulis paragraf.

Data yang diperoleh dari hasil kemampuan menulis paragraf argumentatif dan paragraf persuasif berupa angka. Data hasil evaluasi akan dianalisis secara kuantitatif dengan menggunakan analisis deskriptif dan data hasil pelaksanaan wawancara, observasi, dan tes unjuk kerja akan dianalisis dengan kualitatif. Penilaian tersebut dapat dilihat dari persentase siswa yang mengalami kemajuan dari tiap pertemuan.

Perhitungan nilai dihitung dengan menggunakan rumus berikut.

$$
\mathrm{N}=\frac{\text { Jumlah Skor Perolehan }}{\text { Jumlah Skor Maksimum }} \times \text { skor ideal } 100
$$

Hasil perhitungan tersebut kemudian disesuaikan dengan parameter penilaian untuk menentukan 
kategori menulis paragraf argumentatif dan paragraf persuasif.

\section{KERANGKA TEORI}

Menurut Tarigan (2008:5), paragraf adalah seperangkat kalimat yang tersusun logis sistematis yang merupakan satu kesatuan ekspresi pikiran yang relevan dan mendukung pikiran pokok yang tersirat dalam keseluruhan karangan. Paragraf adalah satu kesatuan ekpresi yang terdiri atas seperangkat kalimat yang dipergunakan oleh pengarang sebagai alat untuk menyatakan dan menyampaikan jalan pikirannya kepada para pembaca.

Metode inkuiri merupakan kegiatan pembelajaran yang menekankan pada proses berpikir secara kritis dan analitis untuk mencari dan menemukan sendiri jawaban dari masalah yang dipertanyakan. Proses beripikir tersebut biasanya dilakukan melalui tanya jawab antara guru dan siswa. Menurut Sanjaya (2011:265), inkuiri adalah proses pembelajaran yang didasarkan pada pencarian dan penemuan melalui proses berpikir secara sistematis.

Kehadiran media pembelajaran mempunyai arti yang cukup penting dalam proses belajar mengajar karena dalam kegiatan tersebut ketidakjelasan bahan yang disampaikan dapat dibantu dengan menghadirkan media pembelajaran sebagai perantara. Menurut Djamarah dan Zain (2006:120), media adalah alat bantu apa saja yang dapat dijadikan sebagai alat penyalur pesan guru untuk mencapai tujuan pengajaran.

Salah satu jenis media pembelajaran yang dapat digunakan oleh pendidik dalam proses pembelajaran adalah media audio. Media audio berkaitan dengan indra pendengar. Dalam hal ini, pesan yang disampaikan dituangkan dalam lambang-lambang auditif, baik verbal (ke dalam kata-kata atau bahasa lisan) maupun nonverbal, (Ahmad, 2007:59). Media audio adalah media yang hanya mengandalkan kemampuan suara saja, seperti radio, cassete recorder, piringan hitam, (Djamarah dan Zain, 2006:124). Ada beberapa jenis media yang dapat dikelompokkan dalam media audio ini, antara lain radio, alat perekam pita magnetik, dan piringan hitam.

\section{HASIL DAN PEMBAHASAN}

Pembahasan pada bagian ini difokuskan pada paparan data dan temuan peneliti tentang penerapan metode inkuiri dengan menggunakan media audio dalam upaya meningkatkan hasil belajar menulis paragraf yang dilaksanakan dalam dua siklus dan dilaksanakan empat kali pertemuan dalam tiap siklus.

\subsection{Hasil Observasi Belajar Siswa Siklus I}

\subsubsection{Hasil Observasi Belajar Siswa Pertemuan Pertama dan Kedua Siklus I}

Hasil observasi terhadap siswa pada pertemuan pertama siklus I dideskripsikan sebagai berikut.

Tabel 1 Analisis Hasil Observasi Siswa Pertemuan Pertama

\begin{tabular}{|c|c|c|c|}
\hline No. & Perilaku & $\begin{array}{c}\text { Jumlah } \\
\text { Siswa }\end{array}$ & $\%$ \\
\hline \multicolumn{4}{|c|}{ Positif } \\
\hline 1 & $\begin{array}{l}\text { Siswa memerhatikan dan merespon dengan antusias (bertanya, menanggapi, dan membuat } \\
\text { catatan). }\end{array}$ & 13 & 44,83 \\
\hline 2 & Siswa berpartisipasi secara aktif dalam kegiatan pembelajaran. & 13 & 44,83 \\
\hline 3 & $\begin{array}{l}\text { Siswa merespons positif (senang) terhadap pembelajaran melalui metode inkuiri dengan } \\
\text { menggunakan media audio. }\end{array}$ & 29 & 100 \\
\hline 4 & Siswa aktif menjawab dan selalu bertanya apabila menemukan hal yang tidak dimengerti. & 5 & 17,24 \\
\hline 5 & Siswa menulis paragraf dengan sikap yang baik. & 29 & 100 \\
\hline \multicolumn{2}{|r|}{ Rata-rata } & 17,8 & 61,38 \\
\hline \multicolumn{4}{|c|}{ Negatif } \\
\hline 6 & $\begin{array}{l}\text { Siswa tidak memerhatikan penjelasan guru dan melakukan kegiatan yang tidak perlu } \\
\text { (bicara sendiri, mondar-mandir, tiduran, dan membuat catatan yang tidak penting). }\end{array}$ & 16 & 55,17 \\
\hline 7 & Siswa kurang berpartisipasi atau pasif dalam kegiatan pembelajaran. & 16 & 55,17 \\
\hline 8 & $\begin{array}{l}\text { Siswa merespons negatif (tidak memerhatikan) terhadap pembelajaran menulis paragraf } \\
\text { melaui metode inkuiri dengan menggunakan media audio. }\end{array}$ & 0 & 0 \\
\hline 9 & Siswa pasif dan malas untuk bertanya mengenai materi menulis paragraf yang sedang & 24 & 82,76 \\
\hline
\end{tabular}


Abdul Aziz : Menulis Paragraf melalui Metode Inkuiri dengan Menggunakan Media Audio

\begin{tabular}{|c|l|c|c|}
\hline & diajarkan. & & \\
\hline 10 & $\begin{array}{l}\text { Siswa melakukan kegiatan yang tidak perlu pada saat pembelajaran menulis paragraf } \\
\text { (mencontek, tiduran, bercanda, dan sebagainya). }\end{array}$ & 0 & 0 \\
\hline \multicolumn{1}{|c|}{ Rata-rata } & 11 & 38,62 \\
\hline
\end{tabular}

Hasil observasi siswa pertemuan kedua siklus I dideskripsikan sebagai berikut.

Tabel 2 Analisis Hasil Observasi Siswa Pertemuan Kedua

\begin{tabular}{|c|c|c|c|}
\hline No. & Perilaku & $\begin{array}{c}\text { Jumlah } \\
\text { Siswa }\end{array}$ & $\%$ \\
\hline \multicolumn{4}{|c|}{ Positif } \\
\hline 1 & $\begin{array}{l}\text { Siswa memerhatikan dan merespon dengan antusias (bertanya, menanggapi, dan membuat } \\
\text { catatan). }\end{array}$ & 19 & 67,86 \\
\hline 2 & Siswa berpartisipasi secara aktif dalam kegiatan pembelajaran. & 17 & 60,71 \\
\hline 3 & $\begin{array}{l}\text { Siswa merespons positif (senang) terhadap pembelajaran melalui metode inkuiri dengan } \\
\text { menggunakan media audio. }\end{array}$ & 28 & 96,55 \\
\hline 4 & Siswa aktif menjawab dan selalu bertanya apabila menemukan hal yang tidak dimengerti. & 21 & 72,41 \\
\hline 5 & Siswa menulis paragraf dengan sikap yang baik. & 28 & 96,55 \\
\hline \multicolumn{2}{|r|}{ Rata-rata } & 22,6 & 78.82 \\
\hline \multicolumn{4}{|c|}{ Negatif } \\
\hline 6 & $\begin{array}{l}\text { Siswa tidak memerhatikan penjelasan guru dan melakukan kegiatan yang tidak perlu } \\
\text { (bicara sendiri, mondar-mandir, tiduran, dan membuat catatan yang tidak penting). }\end{array}$ & 9 & 31,03 \\
\hline 7 & Siswa kurang berpartisipasi atau pasif dalam kegiatan pembelajaran. & 11 & 37,93 \\
\hline 8 & $\begin{array}{l}\text { Siswa merespons negatif (tidak memerhatikan) terhadap pembelajaran menulis paragraf } \\
\text { melaui metode inkuiri dengan menggunakan media audio. }\end{array}$ & 0 & 0 \\
\hline 9 & $\begin{array}{l}\text { Siswa pasif dan malas untuk bertanya mengenai materi menulis paragraf yang sedang } \\
\text { diajarkan. }\end{array}$ & 7 & 24,14 \\
\hline 10 & $\begin{array}{l}\text { Siswa melakukan kegiatan yang tidak perlu pada saat pembelajaran menulis paragraf } \\
\text { (mencontek, tiduran, bercanda, dan sebagainya). }\end{array}$ & 0 & 0 \\
\hline \multicolumn{2}{|r|}{ Rata-rata } & 5,4 & 18,62 \\
\hline
\end{tabular}

\subsubsection{Analisis Hasil Observasi Siswa Pertemuan Pertama dan Kedua Siklus I}

Terdapat perubahan sikap siswa selama proses pembelajaran berlangsung dalam dua kali pertemuan. Perbedaan selisih perilaku positif pertemuan pertama dan kedua siklus I mencapai $16,55 \%$. Berdasarkan analisis hasil observasi tersebut terdapat peningkatan dari pertemuan pertama ke pertemuan kedua. Peningkatan perilaku sikap positif tersebut disebabkan oleh siswa telah mulai tertarik dengan metode pembelajaran dan media pembelajaran yang digunakan. Meskipun telah menunjukkan peningkatan perilaku positif, peningkatan tersebut belum maksimal. Adapun selisih pengurangan perilaku negatif dari pertemuan pertama ke pertemuan kedua mencapai $20 \%$. Selisih tersebut menunjukkan bahwa terdapat perubahan perilaku yang dilakukan oleh siswa.

\subsubsection{Hasil Observasi Belajar Siswa Pertemuan Ketiga dan Keempat Siklus I}

Hasil observasi siswa pertemuan ketiga siklus I dideskripsikan sebagai berikut.

Tabel 3 Analisis Hasil Observasi Siswa Pertemuan Ketiga

\begin{tabular}{|c|c|c|c|}
\hline No. & Perilaku & $\begin{array}{c}\text { Jumlah } \\
\text { Siswa }\end{array}$ & $\%$ \\
\hline & Positif & & \\
\hline 1 & Siswa memerhatikan dan merespon dengan antusias (bertanya, menanggapi, dan membuat & 20 & 68,97 \\
\hline
\end{tabular}


Abdul Aziz : Menulis Paragraf melalui Metode Inkuiri dengan Menggunakan Media Audio

\begin{tabular}{|c|c|c|c|}
\hline & catatan). & & \\
\hline 2 & Siswa berpartisipasi secara aktif dalam kegiatan pembelajaran. & 27 & 93,10 \\
\hline 3 & $\begin{array}{l}\text { Siswa merespons positif (senang) terhadap pembelajaran melalui metode inkuiri dengan } \\
\text { menggunakan media audio. }\end{array}$ & 28 & 96,55 \\
\hline 4 & Siswa aktif menjawab dan selalu bertanya apabila menemukan hal yang tidak dimengerti. & 28 & 96,55 \\
\hline 5 & Siswa menulis paragraf dengan sikap yang baik. & 28 & 96,55 \\
\hline \multicolumn{2}{|r|}{ Rata-rata } & 26,2 & 90,34 \\
\hline \multicolumn{4}{|c|}{ Negatif } \\
\hline 6 & $\begin{array}{l}\text { Siswa tidak memerhatikan penjelasan guru dan melakukan kegiatan yang tidak perlu (bicara } \\
\text { sendiri, mondar-mandir, tiduran, dan membuat catatan yang tidak penting). }\end{array}$ & 8 & 27,57 \\
\hline 7 & Siswa kurang berpartisipasi atau pasif dalam kegiatan pembelajaran. & 1 & 3,44 \\
\hline 8 & $\begin{array}{l}\text { Siswa merespons negatif (tidak memerhatikan) terhadap pembelajaran menulis paragraf } \\
\text { melaui metode inkuiri dengan menggunakan media audio. }\end{array}$ & 0 & 0 \\
\hline 9 & $\begin{array}{l}\text { Siswa pasif dan malas untuk bertanya mengenai materi menulis paragraf yang sedang } \\
\text { diajarkan. }\end{array}$ & 0 & 0 \\
\hline 10 & $\begin{array}{l}\text { Siswa melakukan kegiatan yang tidak perlu pada saat pembelajaran menulis paragraf } \\
\text { (mencontek, tiduran, bercanda, dan sebagainya). }\end{array}$ & 0 & 0 \\
\hline \multicolumn{2}{|r|}{ Rata-rata } & 1,8 & 6,20 \\
\hline
\end{tabular}

Hasil observasi siswa pertemuan keempatsiklus I dideskripsikan sebagai berikut.

Tabel 4 Analisis Hasil Observasi Siswa Pertemuan Keempat

\begin{tabular}{|c|c|c|c|}
\hline No. & Perilaku & $\begin{array}{c}\text { Jumlah } \\
\text { Siswa }\end{array}$ & $\%$ \\
\hline \multicolumn{4}{|c|}{ Positif } \\
\hline 1 & $\begin{array}{l}\text { Siswa memerhatikan dan merespon dengan antusias (bertanya, menanggapi, dan membuat } \\
\text { catatan). }\end{array}$ & 23 & 79,31 \\
\hline 2 & Siswa berpartisipasi secara aktif dalam kegiatan pembelajaran. & 27 & 93,10 \\
\hline 3 & $\begin{array}{l}\text { Siswa merespons positif (senang) terhadap pembelajaran melalui metode inkuiri dengan } \\
\text { menggunakan media audio. }\end{array}$ & 28 & 96,55 \\
\hline 4 & Siswa aktif menjawab dan selalu bertanya apabila menemukan hal yang tidak dimengerti. & 28 & 96,55 \\
\hline 5 & Siswa menulis paragraf dengan sikap yang baik. & 28 & 96,55 \\
\hline \multicolumn{2}{|r|}{ Rata-rata } & 26,8 & 92,41 \\
\hline \multicolumn{4}{|c|}{ Negatif } \\
\hline 6 & $\begin{array}{l}\text { Siswa tidak memerhatikan penjelasan guru dan melakukan kegiatan yang tidak perlu (bicara } \\
\text { sendiri, mondar-mandir, tiduran, dan membuat catatan yang tidak penting). }\end{array}$ & 5 & 17,24 \\
\hline 7 & Siswa kurang berpartisipasi atau pasif dalam kegiatan pembelajaran. & 1 & 3,45 \\
\hline 8 & $\begin{array}{l}\text { Siswa merespons negatif (tidak memerhatikan) terhadap pembelajaran menulis paragraf } \\
\text { melaui metode inkuiri dengan menggunakan media audio. }\end{array}$ & 0 & 0 \\
\hline 9 & $\begin{array}{l}\text { Siswa pasif dan malas untuk bertanya mengenai materi menulis paragraf yang sedang } \\
\text { diajarkan. }\end{array}$ & 0 & 0 \\
\hline 10 & $\begin{array}{l}\text { Siswa melakukan kegiatan yang tidak perlu pada saat pembelajaran menulis paragraf } \\
\text { (mencontek, tiduran, bercanda, dan sebagainya). }\end{array}$ & 0 & 0 \\
\hline \multicolumn{2}{|r|}{ Rata-rata } & 1,2 & 4,14 \\
\hline
\end{tabular}

\subsubsection{Analisis Hasil Observasi Siswa}

Pertemuan Ketiga dan Keempat Siklus I

Selisih perilaku pertemuan ketiga dan pertemuan keempat cukup jauh. Pada pertemuan ketiga, persentase perilaku positif sebanyak $90,34 \%$ dan persentase pertemuan keempat sebanyak 92,41\%. Jadi, selisih perilaku positif antara perilaku ketiga dan keempat sebanyak 2,06\%. Adapun persentase perilaku 
negatif pertemuan ketiga sebanyak $6,20 \%$ dan pertemuan keempat sebanyak 4,14\%. Jadi, selisih antara pertemuan ketiga dan pertemuan keempat sebanyak 2,06\%. Berdasarkan hasil perhitungan tersebut diketahui bahwa persentase siswa yang melakukan perilaku negatif menurun sebanyak $2,06 \%$.

Dengan adanya peningkatan persentase perilaku positif dan penurunan perilaku negatif, dapat disimpulkan bahwa perilaku siswa dari pertemuan ketiga ke pertemuan keempat mengalami peningkatan.

\subsection{Hasil Wawancara terhadap Guru Siklus I}

Berdasarkan hasil wawancara yang dilakukan terhadap guru, diketahui bahwa siswa cukup berminat dengan penerapan metode inkuiri dengan menggunakan media audio. Menurutnya, penggunaan metode inkuiri dengan menggunakan media audio dapat mengembangkan imajinasi siswa, merangsang partisipasi aktif siswa, dan menggugah rasa ingin tahu siswa. Metode inkuiri dapat melatih kemandirian siswa dalam belajar dan mengerjakan tugas-tugas sedangkan penggunaan media audio dapat mengatasi rasa jenuh siswa dalam belajar terutama belajar paragraf. Media audio juga dapat menghibur siswa dan meningkatkan semangat siswa dalam belajar.

\subsection{Hasil Wawancara terhadap Siswa Siklus I}

Berdasarkan hasil wawancara dengan siswa, diketahui bahwa pada siklus I ini, siswa tidak terlalu merasa tertarik dengan materi pelajaran dan masih ada yang menjadi kesulitan dalam pembelajaran tersebut. Salah satu hal yang sulit diterapkan dan diperhatikan siswa dalam menulis paragraf adalah pemilihan kata. Akan tetapi, siswa tertarik dengan penggunaan metode dan media pembelajaran yang diterapkan karena menurutnya dapat memudahkan siswa dalam dalam belajar menulis paragraf. Dengan menggunakan metode dan media tersebut, siswa merasa tidak jenuh dalam proses pembelajaran. Penggunaan media audio ini menjadi salah satu penghibur bagi siswa. Media audio dapat memberikan semangat bagi siswa dalam belajar.

\subsection{Hasil Observasi Belajar Siswa Siklus II}

\subsubsection{Hasil Observasi Belajar Siswa Pertemuan Pertama dan Kedua Siklus II}

Hasil observasi terhadap siswa pada pertemuan pertama siklus II dideskripsikan sebagai berikut.

Tabel 5. Hasil Observasi Siswa Pertemuan Pertama Siklus II

\begin{tabular}{|c|c|c|c|}
\hline No. & Perilaku & $\begin{array}{c}\text { Jumlah } \\
\text { Siswa }\end{array}$ & $\%$ \\
\hline \multicolumn{4}{|c|}{ Positif } \\
\hline 1 & $\begin{array}{l}\text { Siswa memerhatikan dan merespon dengan antusias (bertanya, menanggapi, dan membuat } \\
\text { catatan). }\end{array}$ & 22 & 75,86 \\
\hline 2 & Siswa berpartisipasi secara aktif dalam kegiatan pembelajaran. & 16 & 55,17 \\
\hline 3 & $\begin{array}{l}\text { Siswa merespons positif (senang) terhadap pembelajaran melalui metode inkuiri dengan } \\
\text { menggunakan media audio. }\end{array}$ & 29 & 100 \\
\hline 4 & Siswa aktif menjawab dan selalu bertanya apabila menemukan hal yang tidak dimengerti. & 22 & 75,86 \\
\hline 5 & Siswa menulis paragraf dengan sikap yang baik. & 29 & 100 \\
\hline \multicolumn{2}{|r|}{ Rata-rata } & 23,6 & 81,38 \\
\hline \multicolumn{4}{|c|}{ Negatif } \\
\hline 6 & $\begin{array}{l}\text { Siswa tidak memerhatikan penjelasan guru dan melakukan kegiatan yang tidak perlu (bicara } \\
\text { sendiri, mondar-mandir, tiduran, dan membuat catatan yang tidak penting). }\end{array}$ & 7 & 24,14 \\
\hline 7 & Siswa kurang berpartisipasi atau pasif dalam kegiatan pembelajaran. & 13 & 44,83 \\
\hline 8 & $\begin{array}{l}\text { Siswa merespons negatif (tidak memerhatikan) terhadap pembelajaran menulis paragraf } \\
\text { melaui metode inkuiri dengan menggunakan media audio. }\end{array}$ & 0 & 0 \\
\hline 9 & $\begin{array}{l}\text { Siswa pasif dan malas untuk bertanya mengenai materi menulis paragraf yang sedang } \\
\text { diajarkan. }\end{array}$ & 7 & 24,14 \\
\hline 10 & $\begin{array}{l}\text { Siswa melakukan kegiatan yang tidak perlu pada saat pembelajaran menulis paragraf } \\
\text { (mencontek, tiduran, bercanda, dan sebagainya). }\end{array}$ & 0 & 0 \\
\hline \multicolumn{2}{|r|}{ Rata-rata } & 5,4 & 18,62 \\
\hline
\end{tabular}


Hasil observasi siswa pertemuan kedua siklus II dideskripsikan sebagai berikut.

Tabel 6. Hasil Observasi Siswa Pertemuan Kedua Siklus II

\begin{tabular}{|c|c|c|c|}
\hline No. & Perilaku & $\begin{array}{c}\text { Jumlah } \\
\text { Siswa }\end{array}$ & $\%$ \\
\hline \multicolumn{4}{|c|}{ Positif } \\
\hline 1 & $\begin{array}{l}\text { Siswa memerhatikan dan merespon dengan antusias (bertanya, menanggapi, dan membuat } \\
\text { catatan). }\end{array}$ & 25 & 86,21 \\
\hline 2 & Siswa berpartisipasi secara aktif dalam kegiatan pembelajaran. & 29 & 100 \\
\hline 3 & $\begin{array}{l}\text { Siswa merespons positif (senang) terhadap pembelajaran melalui metode inkuiri dengan } \\
\text { menggunakan media audio. }\end{array}$ & 29 & 100 \\
\hline 4 & Siswa aktif menjawab dan selalu bertanya apabila menemukan hal yang tidak dimengerti. & 29 & 100 \\
\hline 5 & Siswa menulis paragraf dengan sikap yang baik. & 29 & 100 \\
\hline \multicolumn{2}{|r|}{ Rata-rata } & 34 & 117,24 \\
\hline \multicolumn{4}{|c|}{ Negatif } \\
\hline 6 & $\begin{array}{l}\text { Siswa tidak memerhatikan penjelasan guru dan melakukan kegiatan yang tidak perlu } \\
\text { (bicara sendiri, mondar-mandir, tiduran, dan membuat catatan yang tidak penting). }\end{array}$ & 4 & 13,79 \\
\hline 7 & Siswa kurang berpartisipasi atau pasif dalam kegiatan pembelajaran. & 0 & 0 \\
\hline 8 & $\begin{array}{l}\text { Siswa merespons negatif (tidak memerhatikan) terhadap pembelajaran menulis paragraf } \\
\text { melaui metode inkuiri dengan menggunakan media audio. }\end{array}$ & 0 & 0 \\
\hline 9 & $\begin{array}{l}\text { Siswa pasif dan malas untuk bertanya mengenai materi menulis paragraf yang sedang } \\
\text { diajarkan. }\end{array}$ & 0 & 0 \\
\hline 10 & $\begin{array}{l}\text { Siswa melakukan kegiatan yang tidak perlu pada saat pembelajaran menulis paragraf } \\
\text { (mencontek, tiduran, bercanda, dan sebagainya). }\end{array}$ & 0 & 0 \\
\hline \multicolumn{2}{|r|}{ Rata-rata } & 0,8 & 2,76 \\
\hline
\end{tabular}

\subsubsection{Analisis Hasil Observasi Siswa Pertemuan Pertama dan Kedua Siklus II}

Selisih perilaku pertemuan pertama dan pertemuan kedua siklus II cukup jauh. Pada pertemuan pertama, persentase perilaku positif sebanyak $81,38 \%$ dan persentase pertemuan kedua sebanyak $117,24 \%$. Jadi, selisih perilaku positif antara perilaku pertama dan kedua sebanyak 35,86\%. Berdasarkan hasil tersebut diketahui bahwa terjadi peningkatan pada siswa yang melakukan perilaku positif dari pertemuan pertama ke pertemuan kedua, sedangkan persentase perilaku negatif pertemuan pertama sebanyak $18,62 \%$ dan pertemuan kedua sebanyak $2,76 \%$. Jadi, selisih antara pertemuan pertama dan pertemuan kedua adalah $15,86 \%$. Berdasarkan hasil perhitungan tersebut, diketahui bahwa persentase siswa yang melakukan perilaku negatif menurun sebanyak $15,86 \%$. Dengan adanya peningkatan persentase perilaku positif dan penurunan persentase perilaku negatif, dapat disimpulkan bahwa perilaku siswa dari pertemuan pertama ke pertemuan kedua mengalami peningkatan.

\subsubsection{Hasil Observasi Belajar SiswaPertemuan Ketiga dan Keempat Siklus II}

Hasil observasi terhadap siswa pada pertemuan ketiga siklus II dideskripsikan sebagai berikut.

Tabel 4.10 Hasil Observasi Siswa Pertemuan Ketiga Siklus II

\begin{tabular}{|c|l|c|c|}
\hline No. & \multicolumn{1}{|c|}{ Perilaku } & $\begin{array}{c}\text { Jumlah } \\
\text { Siswa }\end{array}$ & \% \\
\hline & \multicolumn{1}{|c|}{ Positif } & & \\
\hline 1 & $\begin{array}{l}\text { Siswa memerhatikan dan merespon dengan antusias (bertanya, menanggapi, dan membuat } \\
\text { catatan). }\end{array}$ & 26 & 89,66 \\
\hline 2 & Siswa berpartisipasi secara aktif dalam kegiatan pembelajaran. & 25 & 86,21 \\
\hline 3 & Siswa merespons positif (senang) terhadap pembelajaran melalui metode inkuiri dengan & 29 & 100 \\
\hline
\end{tabular}


Abdul Aziz : Menulis Paragraf melalui Metode Inkuiri dengan Menggunakan Media Audio

\begin{tabular}{|c|c|c|c|}
\hline & menggunakan media audio. & & \\
\hline 4 & Siswa aktif menjawab dan selalu bertanya apabila menemukan hal yang tidak dimengerti. & 29 & 100 \\
\hline 5 & Siswa menulis paragraf dengan sikap yang baik. & 29 & 100 \\
\hline \multicolumn{2}{|r|}{ Rata-rata } & 27,6 & 95,17 \\
\hline \multicolumn{4}{|c|}{ Negatif } \\
\hline 6 & $\begin{array}{l}\text { Siswa tidak memerhatikan penjelasan guru dan melakukan kegiatan yang tidak perlu } \\
\text { (bicara sendiri, mondar-mandir, tiduran, dan membuat catatan yang tidak penting). }\end{array}$ & 3 & 10,34 \\
\hline 7 & Siswa kurang berpartisipasi atau pasif dalam kegiatan pembelajaran. & 4 & 13,80 \\
\hline 8 & $\begin{array}{l}\text { Siswa merespons negatif (tidak memerhatikan) terhadap pembelajaran menulis paragraf } \\
\text { melaui metode inkuiri dengan menggunakan media audio. }\end{array}$ & 0 & 0 \\
\hline 9 & $\begin{array}{l}\text { Siswa pasif dan malas untuk bertanya mengenai materi menulis paragraf yang sedang } \\
\text { diajarkan. }\end{array}$ & 0 & 0 \\
\hline 10 & $\begin{array}{l}\text { Siswa melakukan kegiatan yang tidak perlu pada saat pembelajaran menulis paragraf } \\
\text { (mencontek, tiduran, bercanda, dan sebagainya). }\end{array}$ & 0 & 0 \\
\hline & Rata-rata & 1,4 & 4,83 \\
\hline
\end{tabular}

Hasil observasi siswa pertemuan keempat siklus II dideskripsikan sebagai berikut.

Tabel 4.11Hasil Observasi Siswa Pertemuan Keempat Siklus II

\begin{tabular}{|c|c|c|c|}
\hline No. & Perilaku & $\begin{array}{c}\text { Jumlah } \\
\text { Siswa }\end{array}$ & $\%$ \\
\hline \multicolumn{4}{|c|}{ Positif } \\
\hline 1 & $\begin{array}{l}\text { Siswa memerhatikan dan merespon dengan antusias (bertanya, menanggapi, dan membuat } \\
\text { catatan). }\end{array}$ & 28 & 96,55 \\
\hline 2 & Siswa berpartisipasi secara aktif dalam kegiatan pembelajaran. & 27 & 93,10 \\
\hline 3 & $\begin{array}{l}\text { Siswa merespons positif (senang) terhadap pembelajaran melalui metode inkuiri dengan } \\
\text { menggunakan media audio. }\end{array}$ & 29 & 100 \\
\hline 4 & Siswa aktif menjawab dan selalu bertanya apabila menemukan hal yang tidak dimengerti. & 29 & 100 \\
\hline 5 & Siswa menulis paragraf dengan sikap yang baik. & 29 & 100 \\
\hline \multicolumn{2}{|r|}{ Rata-rata } & 28,4 & 97,93 \\
\hline \multicolumn{4}{|c|}{ Negatif } \\
\hline 6 & $\begin{array}{l}\text { Siswa tidak memerhatikan penjelasan guru dan melakukan kegiatan yang tidak perlu (bicara } \\
\text { sendiri, mondar-mandir, tiduran, dan membuat catatan yang tidak penting). }\end{array}$ & 1 & 3,45 \\
\hline 7 & Siswa kurang berpartisipasi atau pasif dalam kegiatan pembelajaran. & 2 & 6,90 \\
\hline 8 & $\begin{array}{l}\text { Siswa merespons negatif (tidak memerhatikan) terhadap pembelajaran menulis paragraf } \\
\text { melaui metode inkuiri dengan menggunakan media audio. }\end{array}$ & 0 & 0 \\
\hline 9 & $\begin{array}{l}\text { Siswa pasif dan malas untuk bertanya mengenai materi menulis paragraf yang sedang } \\
\text { diajarkan. }\end{array}$ & 0 & 0 \\
\hline 10 & $\begin{array}{l}\text { Siswa melakukan kegiatan yang tidak perlu pada saat pembelajaran menulis paragraf } \\
\text { (mencontek, tiduran, bercanda, dan sebagainya). }\end{array}$ & 0 & 0 \\
\hline \multicolumn{2}{|r|}{ Rata-rata } & 0.6 & 2,07 \\
\hline
\end{tabular}

\subsubsection{Analisis Hasil Observasi Siswa Pertemuan Ketiga dan Keempat Siklus II}

Selisih perilaku pertemuan ketiga dan pertemuan keempat siklus II tidak terlalu jauh. Pada pertemuan ketiga, persentase perilaku positif sebanyak $95,17 \%$ dan persentase pertemuan keempat sebanyak 97,93\%. Jadi, selisih perilaku positif antara pertemuan ketiga dan keempat adalah 2,76\%. Berdasarkan hasil tersebut, diketahui bahwa terjadi peningkatan pada siswa yang melakukan perilaku positif dari pertemuan ketiga ke pertemuan keempat, sedangkan perilaku negatif mengalami penurunan pada pertemuan ketiga, yakni sebanyak $4,83 \%$ dan $2,07 \%$ pada pertemuan keempat. Jadi, selisih antara pertemuan ketiga dan pertemuan keempat sebanyak 2,76\%. Berdasarkan hasil perhitungan tersebut, diketahui bahwa persentase 
siswa yang melakukan perilaku negatif menurun sebanyak $2,76 \%$. Dengan adanya peningkatan persentase perilaku positif dan penurunan perilaku negatif, dapat disimpulkan bahwa perilaku siswa dari pertemuan ketiga ke pertemuan keempat mengalami peningkatan.

\subsection{Hasil Wawancara terhadap Guru Siklus II}

Berdasarkan hasil wawancara kepada guru, diketahui bahwa siswa sangat berminat dengan penerapan metode inkuiri dengan menggunakan media audio. Menurutnya, dengan menerapkan metode inkuiri dengan menggunakan media audio, guru dapat menyajikan lagu-lagu yang dapat merangsang partisipasi aktif siswa. Sambil mendengarkan lagu, siswa dapat melakukan kegiatankegiatan lain yang menunjang pencapaian tujuan pembelajaran. Penggunaan metode inkuiri dengan media audio dapat memicu antusiasme dan keaktifan siswa dalam proses pembelajaran, terutama dalam pembelajaran menulis paragraf. Hal itu dapat dilihat dari antusias siswa dalam mengikuti pembelajaran seperti siswa aktif bertanya, menanggapi, dan membuat catatan-catatan kecil.

\subsection{Hasil Wawancara terhadap Siswa Siklus II}

Berdasarkan hasil wawancara dengan siswa tersebut, diketahui bahwa siswa sangat tertarik dengan penggunaan metode dan media pembelajaran yang diterapkan karena dapat menghibur, meningkatkan semangat belajar, dan menghilangkan kebosanan dalam belajar menulis paragraf. Menurut pendapat siswa, pembelajaran menulis paragraf merupakan pembelajaran yang menantang, tetapi masih ada yang menjadi kesulitan dalam pembelajaran tersebut. Salah satu hal yang sulit diterapkan dan diperhatikan siswa dalam menulis paragraf adalah penggunaan EYD.

\subsection{Pembahasan Hasil Penelitian}

Pembahasan hasil penelitian penerapan metode inkuiri dengan menggunakan media audio terhadap pembelajaran menulis paragraf pada siswa kelas $X_{1}$ SMA DDI Alliritengae, Kabupaten Maros, meliputi pembahasan pelaksanaan penelitian dan pembahasan hasil evaluasi siklus I dan siklus II. Jenis penelitian yang dilakukan adalah penelitian tindakan kelas yang dilakukan dalam dua siklus, yang masing-masing siklus dilakukan dalam empat tahap, yaitu tahap perencanaan, pelaksanaan, observasi, dan evaluasi.

\subsubsection{Pembahasan Pelaksanaan Pembelajaran Menulis Paragraf}

Pada proses pelaksanaan, sikap dan perilaku siswa mengalami perubahan. Hal tersebut dapat dilihat berdasarkan perilaku positif dan perilaku negatif siswa yang diteliti pada setiap pertemuan. Berdasarkan hasil observasi yang telah dilakukan, dapat diketahui bahwa dari pertemuan ke pertemuan selanjutnya perubahan perilaku siswa cukup memuaskan. Setiap pertemuan, semakin banyak siswa yang melakukan perilaku positif, sebaliknya semakin sedikit siswa yang melakukan perilaku negatif. Hal itu menandakan bahwa telah terjadi perubahan perilaku siswa pada setiap pertemuan. Perubahan tersebut adalah terjadinya peningkatan persentase perilaku positif setiap pertemuan. Perubahan yang terjadi disebabkan oleh siswa telah menyukai penerapan metode inkuiri yang menggunakan media audio.

Pada siklus I, persentase siswa yang melakukan kegiatan positif masih kurang, seperti (1) siswa memerhatikan dan merespon dengan antusias (bertanya, menanggapi, dan membuat catatan), (2) siswa berpartisipasi aktif dalam kegiatan pembelajaran, (3) siswa merespons positif (senang) terhadap pembelajaran melalui metode inkuiri dengan menggunakan media audio, (4) siswa aktif menjawab dan selalu bertanya apabila menemukuan hal yang tidak dimengerti, (5) siswa menulis paragraf dengan sikap yang baik. Selain itu, yang menjadi kekurangan siklus I adalah (1) penjelasan guru tentang materi pelajaran belum maksimal, (2) penjelasan guru tentang langkah-langkah metode pembelajaran belum maksimal, (3) siswa belum memahami dengan baik langkah-langkah metode pembelajaran, kemampuan siswa dalam menulis paragraf dengan memerhatikan kelima hal yang menjadi penilaian utama, yaitu kohesi, koherensi, penggunaan EYD, penggunaan bahasa, dan diksi (pilihan kata) masih kurang, dan (5) masih ada siswa yang menulis paragraf tidak sesuai dengan isi lagu. 


\subsubsection{Pembahasan Peningkatan Hasil Penilaian Pembelajaran Menulis Paragraf}

Pada tahap evaluasi atau penilaian juga terjadi peningkatan kemampuan menulis paragraf dengan penerapan metode inkuiri dengan menggunakan media audio dari siklus I ke siklus II. Pembahasan hasil penelitian mengacu pada tiga ranah, yaitu ranah kognitif, afektif, dan psikomotorik. Secara keseluruhan peningkatan hasil tes dari siklus I ke siklus II sebanyak 11,47. Nilai rata-rata kelas yang diperoleh siswa pada siklus I sebanyak 74,86 dan nilai rata-rata kelas siklus II sebanyak 86,33. Hasil tersebut menunjukkan bahwa telah terjadi peningkatan dari siklus I ke siklus II.

Selanjutnya, penilaian tes menulis paragraf terdiri dari lima aspek yaitu (1) kohesi, (2) koherensi, (3) penggunaan EYD, (4) penggunaan bahasa, dan (5) pilihan kata (diksi). Pada hasil tes menulis paragraf juga terjadi peningkatan, baik pada paragraf argumentatif maupun paragraf persuasif. Peningkatan hasil tes terjadi pada masing-masing aspek.

Pada aspek kohesi paragraf argumentatif siklus I, nilai rata-rata kelas yang dicapai siswa sebanyak 84,20 meningkat menjadi 88,51 pada siklus II. Adapun nilai rata-rata siswa pada aspek kohesi paragraf persuasif siklus I yang mencapai 82,76 meningkat menjadi 93,97 pada siklus II. Pada aspek koherensi paragraf argumentatif siklus I, siswa mencapai nilai rata-rata kelas 80,46 dan mengalami peningkatan menjadi 87,07 pada siklus II. Nilai ratarata kelas aspek koherensi paragraf persuasif siklus I 77,59 dan mengalami peningkatan menjadi 94,25 pada siklus II.

Pada aspek penggunaan EYD paragraf argumentatif siklus I, siswa mencapai nilai rata-rata kelas 71,55 dan mengalami peningkatan pada siklus II menjadi 89,86. Nilai rata-rata aspek penggunaan EYD paragraf persuasif siklus I mencapai 74,43 dan mengalami peningkatan menjadi 94,25.

Pada aspek penggunaan bahasa paragraf argumentatif siklus I, nilai rata-rata kelas mencapai 76,15 dan mengalami peningkatan menjadi 83,33 pada siklus II. Nilai rata-rata kelas aspek penggunaan bahasa paragraf persuasif siklus I mencapai 76,86 dan mengalami peningkatan menjadi 95,65.

Pada aspek pilihan kata (diksi) paragraf argumentatif, nilai rata-rata kelas siswa mencapai
66,38 dan mengalami peningkatan menjadi 76,15. Nilai rata-rata kelas aspek pilihan kata (diksi) paragraf persuasif mencapai 74,43 dan mengalami peningkatan menjadi 92,53.

\section{PENUTUP}

\subsection{Simpulan}

Berdasarkan hasil analisis data dan pembahasan, penerapan metode inkuiri dengan menggunakan media audio dapat meningkatkan kemampuan menulis paragraf siswa kelas $\mathrm{X}_{1}$ SMA DDI Alliritengae, Kabupaten Maros. Berdasarkan uraian di atas, penelitian ini dapat disimpulkan sebagai berikut.

1. Pelaksanaan pembelajaran menulis paragraf melalui metode inkuiri dengan menggunakan media audio menunjukkan perubahan perilaku dalam pembelajaran ke arah positif. Hal tersebut membuktikan bahwa penerapan metode inkuiri dengan menggunakan media audio dapat meningkatkan kemampuan menulis paragraf siswa, baik paragraf argumentatif maupun paragraf persuasif. Perubahan perilaku siswa tampak pada peningkatan kreativitas dan keterampilan siswa yang mengalami perubahan dari siklus I ke siklus II. Pada siklus I, pada umumnya siswa yang belum terlalu memahami paragraf dan belum mampu menulis paragraf dengan baik dan benar mengalami perubahan pada siklus II. Siswa menjadi memahami paragraf dengan baik dan mampu menulis paragraf yang baik dan benar.

2. Hasil penelitian menunjukkan bahwa penerapan metode inkuiri dengan menggunakan media audio dapat meningkatkan pembelajaran menulis paragraf. Hasil analisis tes secara keseluruhan dari siklus I ke siklus II menunjukkan peningkatan, mulai penilaian ranah kognitif, afektif, hingga psikomotorik.

\subsection{Saran}

Saran yang dapat diajukan dari penelitian ini adalah sebagai berikut.

1. Pelaksanaan pembelajaran menulis paragraf hendaknya menggunakan metode inkuiri dengan media audio karena menunjukkan perubahan perilaku dalam pembelajaran ke arah positif. Selain itu, dapat meningkatkan kemampuan 
Abdul Aziz : Menulis Paragraf melalui Metode Inkuiri dengan Menggunakan Media Audio

menulis paragraf siswa, baik paragraf argumentatif maupun paragraf persuasif.

2. Penerapan metode inkuiri dengan menggunakan media audio dapat juga dicoba dilakukan dalam pembelajaran menulis paragraf lainnya untuk mendapatkan proses dan hasil belajar yang lebih baik.

\section{DAFTAR PUSTAKA}

Ahmad. 2007. Strategi Belajar Mengajar. Jakarta: Rieneka Cipta.

Akhadiah, dkk. 2008. Pembinaan Kemampuan Menulis Bahasa Indonesia. Jakarta: Erlangga.

Arikunto, Suharjono, dan Supardi. 2011. Penelitian Tindakan Kelas. Jakarta: Bumi Aksara.

Djamarah, Syaiful Bahri, dan Aswan Zain. 2006. Strategi Belajar Mengajar. Jakarta: Asdi Mahasatya.

Halim, Abdul. 2007. Belajar dan Pembelajaran. Makassar: BP UNM.

Kartono, ST. 2009. Menulis Tanpa Rasa Takut. Yogyakarta: Kanisius.

Nurgiyantoro, Burhan. 2010. Penilaian Pembelajaran Bahasa Berbasis Kompetensi. Yogyakarta: BPFE.

Nurudin. 2007. Dasar-Dasar Penulisan. Malang: Universitas Negeri Malang.

Sanjaya, Wina. 2012. Strategi Pembelajaran: Berorientasi Standar Proses Pendidikan. Bandung: Kencana.

Sudjana, Nana. 2009. Penilaian Hasil Proses Pembelajaran Mengajar. Bandung: Remaja Rosdakarya.

Suyatno.2004. Teknik Pembelajaran Bahasa dan Sastra. Surabaya: SIC.

Tarigan, Henry Guntur. 2008. Menulis sebagai Suatu Keterampilan Berbahasa. Bandung: Angkasa. 
Abdul Aziz : Menulis Paragraf melalui Metode Inkuiri dengan Menggunakan Media Audio 